\title{
Impact of food price increases on poverty in Indonesia: empirical evidence from cross-sectional data
}

\author{
Faharuddin Faharuddin \\ Badan Pusat Statistik Republik Indonesia, Jakarta, Indonesia, and \\ M. Yamin, Andy Mulyana and Y. Yunita \\ Faculty of Agriculture, Sriwijaya University, Palembang, Indonesia
}

\begin{abstract}
Purpose - Using cross-sectional household survey data, this paper aims to determine the impact of food price increases on poverty in Indonesia.

Design/methodology/approach - This paper uses the quadratic almost ideal demand system applied to the 2013 Indonesian household survey data. The impact of food price increase on household welfare is calculated using a welfare measure, compensating variation.

Findings - Three food groups with the most outstanding price impact on poverty are rice, vegetables and fish were studied. The $20 \%$ increase in the price of each food group causes an increase in the headcount ratio by 1.360 points (rice), 0.737 points (vegetables) and 0.636 points (fish). Maintaining food price stability for these food groups is very important because the more price increases, the more impact on poverty. Food price policies in rural areas are also more critical than in urban areas because the impact of food price increases in rural areas is higher.
\end{abstract}

Research limitations/implications - This paper does not consider the positive impact of rising food prices on food-producing households.

Practical implications - Implementing appropriate poverty alleviation policies through food policies for main food groups and social protection.

Social implications - Promoting rural development policies and agricultural growth.

Originality/value - This paper contributes to the existing literature by providing empirical results regarding the impact of domestic food prices increase on poverty in Indonesia.

Keywords Food price increase, Poverty, Indonesia, QUAIDS, Compensating variation

Paper type Research paper

\section{Introduction}

Poverty alleviation is the commitment of the Indonesian government as mandated by the National Medium-Term Development Plan (Rencana Pembangunan Jangka Menengah RPJMN) and as an indicator of global development in the Sustainable Development Goals (SDGs). Therefore, through the National Statistical Office (BPS - Statistics Indonesia), the announcement of the poverty rate always draws public attention. Efforts to alleviate poverty need to pay attention to the root causes of poverty, including providing basic needs.

One of the scourges for increasing poverty is the price increase, especially food prices. Rising food prices increase income for food producers, in this case, farmers, but reduce the purchasing power of food consumers, on the other hand. For consumers, the food prices increase directly rise household spending on food. If household income remains unchanged, a

(C) Faharuddin Faharuddin, M. Yamin, Andy Mulyana and Y. Yunita. Published in Journal of Asian Business and Economic Studies. Published by Emerald Publishing Limited. This article is published under the Creative Commons Attribution (CC BY 4.0) licence. Anyone may reproduce, distribute, translate and create derivative works of this article (for both commercial and non-commercial purposes), subject to full attribution to the original publication and authors. The full terms of this licence may be seen at http://creativecommons.org/licences/by/4.0/legalcode
Received 7 June 2021 Revised 6 September 2021 22 November 2021 24 December 2021 Accepted 24 December 2021 
rise in food prices decreases purchasing power and increases poverty. During the 1997-1999 crisis period, for example, a high price increase contributed to the high poverty incidence in Indonesia in the short run. However, the foodstuffs inflation rate in Indonesia in recent years was relatively lower. Therefore, in March 2019, the Indonesian poverty rate was $9.41 \%$ and had consistently declined since 2006 (BPS, 2019). Despite the decline, the poverty rate in Indonesia is still much higher than in neighboring countries such as Malaysia and Thailand (World Bank, 2020). With the above empirical fact between the increase in food inflation and poverty, it is necessary to examine the negative impact of food price increases on poverty. It will be helpful for government policy responses, such as price policy, food aid policy or food export and import policy.

Recent studies on household response to food prices increase in Indonesia at the microlevel have been carried out by Pangaribowo and Tsegai (2011), Widarjono (2012), Faharuddin et al. (2017, 2019), Allo et al. (2018), Devi and Purnomosidi (2019) and Khoiriyah et al. (2020). Unfortunately, these studies only calculate the expenditure/income elasticity and price elasticity to identify the characteristics of each food group. Besides calculating price and income elasticity, some of them also calculated the price impact on household welfare using a compensating variation (CV). They had proposed policy recommendations, but they did not specifically address the rising food price's impact on poverty.

There has been little recent research into the relationship between rising food prices and poverty in Indonesia. From international literature, we found McCulloch (2008), Ivanic et al. (2012), Warr and Yusuf (2013) and Misdawita et al. (2019). McCulloch (2008) and Ivanic et al. (2012) studied increasing rice price impact on poverty in Indonesia, while Warr and Yusuf (2013) use international prices for six food commodities to calculate the poverty impact. Misdawita et al. (2019) used the social accounting matrix to find the effect of four food commodities prices (rice, maize, soybean and sugar) on poverty. Most households in Indonesia, including rural areas, are negatively affected by the increase in rice prices because of decreasing household welfare and increasing poverty. Although these studies were necessary for the government policy responses, it is better to expand them to the impact of other food group prices rather than primary food commodities, rice, maize, soybean or sugar.

This paper aims to examine the impact of food prices' increase on poverty in Indonesia using cross-sectional household survey data. We calculate the food price impact using a welfare measure (CV) based on simulations of food prices increase. Applying the FosterGreer-Thorbeck (FGT) poverty index on household CV-reduced expenditure, we will get the poverty rate after the price's increase. The poverty impact is the changes in the FGT poverty index before and after the price increase. Our main contribution to the literature is to provide the extent impacts of domestic food prices increases of many food groups on poverty, not just the primary food commodities. Information on the effect of food price increase on poverty gives better policymaking on food security and poverty alleviation. Although, in this paper, we do not consider the positive impact of rising food prices on food-producing households.

\section{Literature review}

Poverty is defined as "a pronounced deprivation in well-being" (Haughton and Khandker, 2009). The poor are the people who cannot meet their minimum living standard due to their low income and lack of control over economic resources. In terms of capability deprivation, poverty arises because of the inability to function in society due to a lack of, for example, education, poor health, insecurity and self-confidence.

Although poverty is multidimensional, the most widely used poverty measure is income (or expenditure) poverty. The poverty measure is determined based on the threshold of income called the poverty line. Poor people are those who have income (or expenditure) below the poverty line. The World Bank currently uses a threshold of US $\$ 1.25$ and US $\$ 2$ per capita 
per day in purchasing power parity as a poverty line. However, poverty lines between countries around the world vary much between US $\$ 1$ and US\$40 in 2005 purchasing power parity (Ravallion, 2012).

In Indonesia, poverty is measured using the cost of basic needs approach, which is based on income poverty. The poverty line is the amount of expenditure (in rupiahs) required to meet the minimum basic needs, food and non-food. The poverty line is the sum of the food poverty line and the non-food poverty line. The food poverty line is per capita expenditure (in rupiahs) equivalent to food consumption of 2,100 kcal per capita per day, while the non-food poverty line is per capita expenditure (in rupiahs) to meet the minimum needs such as housing, clothing, education and health. Commodity baskets of basic food needs are represented by 52 food commodities, while non-food basic needs consist of 51 non-food items for urban areas and 47 for rural areas (BPS, 2010).

Empirically, the relationship between rising food prices and household welfare focused on much of the international literature. Some recent studies, for example, conducted by Ivanic and Martin (2008), McCulloch (2008), Valero-Gill and Valero (2008), Robles and Torero (2010), $\mathrm{Vu}$ and Glewwe (2011), De Hoyos and Medvedev (2011), Ivanic et al. (2012), Ferreira et al. (2013), Attanasio et al. (2013), Warr and Yusuf (2013), Fujii (2013), Caracciolo et al. (2013), Ivanic and Martin (2014), Headey (2018), Misdawita et al. (2019), Adekunle et al. (2020) and Hovhannisyan and Shanoyan (2020). These studies report the negative impact of rising food prices on welfare or poverty, although they vary depending on the share of food consumption and household characteristics.

The link between food prices and poverty is summarized as follows. Initially, if household income does not change, an increase in food prices directly increases household budget spend on food and then reduces the purchasing power. Households then make food consumption adjustments by reducing their demand for food or replacing it with other food. Thus, rising food prices impact changes in household food consumption patterns both in quantity and quality. Furthermore, rising food prices will increase poverty rates, but prices are not linear (Ivanic and Martin, 2014). Declining purchasing power makes some households are unable to meet their minimum food needs, especially for the near-poor and vulnerable households. Moreover, the near-poor and vulnerable populations are relatively high in Indonesia (Suryahadi and Sumarto, 2003).

The impact of rising food prices for households that have linkages with the agricultural commodity market may be positive on increasing incomes (de Hoyos and Medvedv, 2011). However, as mentioned by McCulloch (2008), in Indonesia, most are net food consumers so that this positive impact is relatively small, even according to Warr and Yusuf (2013), this positive impact is only received by owners of agricultural land and capital, not by poor farmers. It is also in line with Adekunle et al. (2020) that most farmers in Nigeria are net food buyers, and rising food prices affect welfare losses.

The Hicksian CV is used in the analytical framework of the relationship between food price changes and welfare. CV is the amount of money needed to keep the household at the same level of utility as before the price increase. If prices increase, then $\mathrm{CV}$ value means the amount of money must be given as compensation for price increases so that the household welfare level remains the same as before. If $p^{0}$ and $p^{1}$ denote the price vectors before and after the price increase and $\mathrm{u} 0$ is the initial utility, then $\mathrm{CV}$ is defined as:

$$
\mathrm{CV}=E\left(p^{1}, u^{0}\right)-E\left(p^{0}, u^{0}\right)
$$

where $E\left(p, u^{0}\right)$ is the minimum expenditure at price $p$ to reach the utility level $u^{0}$. A welfare loss is indicated by a positive $\mathrm{CV}$ value, while a negative value means a welfare gain (Hovhannisyan and Shanoyan, 2020). 


\section{JABES}

\section{Data and methodology}

The principal analytical method used in this study is quadratic almost ideal demand systems (QUAIDS), proposed by Banks et al. (1997). Besides QUAIDS, this study also uses CV and poverty indicators to calculate the impact of rising food prices on household welfare and poverty. The scope of this study is the Indonesian territory using data from household surveys, the first quarter of 2013 National Socioeconomic Survey (Survei Sosial Ekonomi Nasional-Susenas) obtained from the National Statistical Office (BPS - Statistics Indonesia). The first quarter of Susenas 2013 collects data on household consumption of more than 200 food commodities in March, with a sample of about 75,000 households throughout Indonesia. This paper uses 2013 Susenas because it covers more complete food commodities than the recent Susenas.

The price of food or food groups calculated using the unit value approach, as well as the ratio of food expenditure to food consumption. The median of the unit value is used to justify the price of the unit value approach. It overcomes the problem of differences in the food quality consumed by households (Deaton, 1987). Following Hoang (2009), we used equations:

$$
v_{i}=\overline{v_{i}}+\varphi_{i} x+\boldsymbol{\theta D}+\varepsilon_{i} \text { and } p_{i}=\overline{\overline{v_{i}}+\widehat{\varepsilon}_{i}}
$$

where $v_{i}=\frac{1}{n_{i}} \sum_{k}\left[v_{i k} \frac{x_{i k}}{x_{i}}\right]$ and $v_{i k}=\frac{x_{i k}}{q_{i k}}$ are, respectively, the unit value of the $i$ th food group and the $k$ th food commodity; $x_{i k}$ is expenditures (in rupiahs) for the $k$ th food commodity on the $i$ th food group; $x_{i}$ is subtotal food expenditure for the $i$ th food group; $x$ is the total food expenditure; $q_{i k}$ is the quantity consumed for the $k$ th food commodity on the $i$ th food group; $n_{i}$ is the number of food commodities of the $i$ th food group; $\boldsymbol{D}$ is a vector of demographic variables; $\varphi_{i}$ and $\boldsymbol{\theta}$ are unknown parameters; $\boldsymbol{\varepsilon}_{i}$ is residual; $\overline{v_{i}}$ and $\overline{\overline{v_{i}}+\widehat{\varepsilon_{i}}}$ denote mean of unit value in community level (census block); and $p_{i}$ is adjusted prices will be used in the QUAIDS model.

The QUAIDS model used in this study is formulated as follows (Poi, 2012):

$$
w_{i}=\alpha_{i}+\sum_{j} \gamma_{i j} \ln p_{j}+\left(\beta_{i}+\boldsymbol{\eta}_{i}^{\prime} \boldsymbol{D}\right) \ln \left[\frac{x}{\bar{m}_{0}(\boldsymbol{D}) a(\boldsymbol{p})}\right]+\frac{\lambda_{i}}{b(\boldsymbol{p}) c(\boldsymbol{p}, \boldsymbol{D})}\left\{\ln \left[\frac{x}{\bar{m}_{0}(\boldsymbol{D}) a(\boldsymbol{p})}\right]\right\}^{2}+u_{i}
$$

where $w_{i}$ is the share of expenditure from the $i$ th food group, $p_{j}$ is the $j$ th food group price, $x$ is the total household expenditure for food, $\boldsymbol{D}$ is the vector of the demographic variable, $\boldsymbol{p}$ is the price vector, $\overline{\boldsymbol{m}}_{0}(\boldsymbol{D})=1+\boldsymbol{\rho}^{\prime} \boldsymbol{D}, c(\boldsymbol{p}, \boldsymbol{D})=\prod_{j} p_{j}^{\eta_{j}^{\prime \boldsymbol{D}}}, \ln a(\boldsymbol{p})=\alpha_{0}+\sum_{i=1}^{n} \alpha_{i} \ln p_{i}+\sum_{i=1}^{n}$ $\sum_{j=1}^{n} \gamma_{i j} \ln p_{i} \ln p_{j}$ is the Stone price index, $b(\boldsymbol{p})=\prod_{i=\mathbf{1}}^{n} p_{i}^{\beta_{i}}$ is a Cobb-Douglas price aggregator, and $\alpha_{i}, \gamma_{i j}, \beta_{i}, \lambda_{i}, \boldsymbol{\eta}_{i}, \boldsymbol{\rho}$ are unknown parameters.

Food consumption patterns often differ according to the demographic characteristics, so we add demographic variables in the above model following Poi (2012). We use the following demographic variables in our QUAIDS model, household size, the number of children under five years old, urban-rural classification, education of the head of household (graduated high school or not), the primary industry of head of the household (agriculture or not) and income groups (the lowest $40 \%, 40 \%$ middle income and $20 \%$ the highest income). We also use 14 groups of food commodities: rice, non-rice cereals, tubers, fish, meat, eggs, milk, vegetables, pulses, fruits, oils and fats, beverage ingredients, spices and other foods.

The restrictions imposed on the QUAIDS model above to conform to the demand theory are adding up $\left(\sum_{i=1}^{n} \alpha_{i}=1 ; \sum_{i=1}^{n} \gamma_{i j}=0 ; \sum_{i=1}^{n} \beta_{i}=0\right)$, homogenous $\left(\sum_{j=1}^{n} \gamma_{i j}=0\right)$ and symmetry $\left(\gamma_{i j}=\gamma_{j i}\right)$. Nonlinearity in parameters and restrictions on demand equations is 
overcome by using an iterative feasible generalized nonlinear least squares method (IFGNLS) to obtain more efficient parameter estimates. The last equation of the demand system must be discarded in the estimation process to avoid the singularity of $u_{i}$ Covariance matrix due to adding-up restriction. The estimation process is carried out using the Stata code developed by Poi (2012) in Stata software.

Following Friedman and Levinson (2002) and Robles and Torero (2010), the impact of changes in food prices on household welfare is calculated using welfare measures, $\mathrm{CV}$, as follows:

$$
\frac{\mathrm{CV}}{x^{0}} \cong \sum_{i=1}^{n} w_{i} \frac{\Delta p_{i}}{p_{i}^{0}}+\frac{1}{2} \sum_{i=1}^{n} \sum_{j=1}^{n} e_{i j}^{*} w_{i} \frac{\Delta p_{i}}{p_{i}^{0}} \frac{\Delta p_{j}}{p_{j}^{0}}
$$

where $x^{0}$ is the initial household food expenditure before the price increase, $p_{i}^{0}$ is the initial food price before the price increase, $e_{i j}^{*}=e_{i j}+e_{i x} w_{j}$ is the compensated cross-price elasticity; $e_{i j}=\frac{\mu_{i j}}{w_{i}}-\delta_{i j}$ is the uncompensated cross-price elasticity; $e_{i x}=\frac{\mu_{i}}{w_{i}}+1$ is the expenditure or income elasticity; $\mu_{i j} \equiv \frac{\partial w_{i}}{\partial \ln p_{j}}=\gamma_{i j}-\mu_{i}\left(\alpha_{i}+\sum_{k} \gamma_{j k} \ln p_{k}\right)-\frac{\lambda_{i}\left(\beta_{i}+\boldsymbol{\eta}_{\boldsymbol{i}}^{\prime} \boldsymbol{D}\right)}{b(\boldsymbol{p}) c(\boldsymbol{p}, \boldsymbol{D})}$ $\left\{\ln \left[\frac{x}{a(\boldsymbol{p})}\right]\right\}^{2} ; \mu_{i} \equiv \frac{\partial w_{i}}{\partial \ln x}=\left(\beta_{i}+\boldsymbol{\eta}_{i}^{\prime} \boldsymbol{D}\right)+\frac{\lambda_{i}}{b(\boldsymbol{p}) c(\boldsymbol{p}, \boldsymbol{D})} \ln \left[\frac{x}{\bar{m}_{0}(\boldsymbol{D}) a(\boldsymbol{p})}\right] ; \delta_{i j}$ is the Kronecker delta $\left(\delta_{i j}=1\right.$ for $i=j$ and $\delta_{i j}=0$ for $i \neq j$ ); and $\frac{\Delta p_{i}}{p_{i}^{0}}$ and $\frac{\Delta p_{j}}{p_{j}^{0}}$ are the magnitude of food price increase used in the simulation process.

Using a different method with $\mathrm{Yu}$ (2014), the $\mathrm{CV}$ value obtained in equation (4) reduces the value of household expenditure after food price increases. The poverty indicator is then calculated using the original value and the reduced value of the household expenditure. The measure of poverty used is the FGT index of Foster et al. (1984):

$$
P_{\alpha}^{*}=\frac{1}{N} \sum_{h=1}^{H} \psi_{h}\left(\frac{z-\bar{x}_{h}^{*}}{z}\right)^{\alpha} I\left(z \geq x_{h}^{*}\right)
$$

where $P_{\alpha}^{*}$ is the poverty measure $(\alpha=0,1,2)$ after food price increase; $N$ is the number of populations; $H$ is the number of households; $\psi_{h}$ is the $h$ th household size; $z$ is the poverty line; ${\overline{x_{h}}}^{*}=\left(x_{h}^{0}-C V\right) / \psi_{h}$ is the reduced value of per capita household expenditure after food price increase; $x_{h}^{0}$ is the initial value of $h$ th household expenditure (both food and nonfood) before price increase; and $I\left(z \geq x_{h}^{*}\right)$ is an indicator function, which is 1 if $z \geq x_{h}^{*}$, and 0 if vice versa. The measure of poverty before the food prices increase $P_{\alpha}$ is obtained by replacing $x_{h}^{*}$ and $\bar{x}_{h}{ }^{*}$ with $x_{h}^{0}$ and ${\overline{x_{h}}}^{0}$, respectively, in the above FGT equation where ${\overline{x_{h}}}^{0}=x_{h}^{0} / \psi_{h}$. $P_{0}$ is the headcount ratio, $P_{1}$ is the poverty gap index and $P_{2}$ is the poverty severity index.

The magnitude of the impact of the increase in food prices on poverty is the difference in the value of the poverty measure between the original value and the new value after the increase in food prices. A similar method was carried out by Fujii (2013) and Caracciolo et al. (2013). Fujii (2013) also reduced the value of household expenditure with CV to calculate the new poverty indicator. By contrast, Caracciolo et al. (2013) added CV values to the poverty line.

To assess the impact of rising food prices on poverty in Indonesia, four simulations of rising food prices are used, a low-price increase of 5\% (Sim 1), a moderate price increase of 10\% (Sim 2), a high price increase of 15\% (Sim 3) and very high increase at 20\% (Sim 4). We 


\title{
JABES
}

apply the 2013 national poverty line, both urban and rural, on household per capita expenditure (before and after simulated price increase) to get the impact of food price increase on poverty.

\section{Results and discussion}

\subsection{Food inflation Dan poverty trend}

Table 1 presents food inflation and poverty trend in Indonesia collected from various publications of BPS - Statistics Indonesia. In 1996-2019, annual general inflation in Indonesia varied from the lowest $2.78 \%$ in 2009 to the highest $77.54 \%$ in 1998 during the economic crisis. General inflation is almost always below two digits (lower than $10 \%$ ), except for six times in 1997, 1998, 2001, 2002, 2005 and 2008. From 2009 to 2014, annual inflation has always been consistently lower than $10 \%$.

Foodstuffs inflation tends to be higher than general inflation, as the annual foodstuffs inflation was above $10 \%$ more often than the general inflation. Double-digit foodstuffs inflation occurred ten times during the 1996-2019 period, in 1997, 1998, 2001, 2005, 2006, 2007, 2008, 2010, 2013 and 2014. Food inflation was also more varied than general inflation, where the lowest inflation was $-5.25 \%$ in 1999 , and the highest was $118.35 \%$ in 1998 . The variation in annual foodstuffs inflation is even greater when viewed by the food group. The highest inflation variation was spices, nuts, oils and fat, while the lower variation was eggs

\begin{tabular}{|c|c|c|c|c|c|}
\hline $\begin{array}{l}\text { Year } \\
(1)\end{array}$ & $\begin{array}{l}\text { General } \\
\text { inflation } \\
(2)\end{array}$ & $\begin{array}{l}\text { Foodstuffs } \\
\text { inflation } \\
(3)\end{array}$ & $\begin{array}{c}\text { Processed food/beverage/ } \\
\text { cigarettes/tobacco inflation } \\
\text { (4) }\end{array}$ & $\begin{array}{c}\text { Poverty } \\
\text { headcount ratio* } \\
\text { (5) }\end{array}$ & $\begin{array}{c}\text { Food expenditure } \\
\text { share** } \\
(6)\end{array}$ \\
\hline 1996 & 6.47 & 6.32 & 4.33 & 19.78 & 50.90 \\
\hline 1997 & 10.31 & 19.92 & 7.82 & - & - \\
\hline 1998 & 77.54 & 118.32 & 94.35 & 25.72 & 55.95 \\
\hline 1999 & 2.01 & -5.25 & 3.60 & 26.03 & 57.61 \\
\hline 2000 & 9.34 & 4.00 & 11.09 & 19.14 & 58.92 \\
\hline 2001 & 12.55 & 12.03 & 14.48 & 18.41 & 55.54 \\
\hline 2002 & 10.03 & 9.13 & 9.18 & 18.20 & 51.67 \\
\hline 2003 & 5.06 & -1.72 & 6.24 & 17.42 & 49.33 \\
\hline 2004 & 6.40 & 6.38 & 4.85 & 16.66 & 47.69 \\
\hline 2005 & 17.11 & 13.91 & 13.71 & 15.97 & 47.50 \\
\hline 2006 & 6.60 & 12.94 & 6.36 & 17.75 & 47.04 \\
\hline 2007 & 6.59 & 11.26 & 6.41 & 16.58 & 44.27 \\
\hline 2008 & 11.06 & 16.35 & 12.53 & 15.42 & 45.08 \\
\hline 2009 & 2.78 & 3.88 & 7.81 & 14.15 & 45.37 \\
\hline 2010 & 6.96 & 15.64 & 6.96 & 13.33 & 46.18 \\
\hline 2011 & 3.79 & 3.64 & 4.51 & 12.49 & 44.29 \\
\hline 2012 & 4.30 & 5.68 & 6.11 & 11.96 & 44.76 \\
\hline 2013 & 8.38 & 11.35 & 7.45 & 11.37 & 44.42 \\
\hline 2014 & 8.36 & 10.57 & 8.11 & 11.25 & 43.72 \\
\hline 2015 & 3.35 & 4.93 & 6.42 & 11.22 & 41.53 \\
\hline 2016 & 3.02 & 5.69 & 5.38 & 10.86 & 41.96 \\
\hline 2017 & 3.61 & 1.26 & 4.10 & 10.64 & 44.61 \\
\hline 2018 & 3.13 & 3.41 & 3.91 & 9.82 & 43.70 \\
\hline 2019 & 2.72 & 4.28 & 3.97 & 9.41 & 43.08 \\
\hline \multicolumn{6}{|c|}{$\begin{array}{l}\text { Note(s): *2011-2019 used data in March } \\
* * \text { Not including tobacco/cigarettes expenditure }\end{array}$} \\
\hline \multicolumn{6}{|c|}{ Source(s): BPS - Statistics Indonesia, various publications } \\
\hline
\end{tabular}

Table 1.

General inflation, foodstuffs inflation, processed food/ beverage/cigarettes/ tobacco inflation, poverty headcount ratio and food expenditure share in Indonesia, 1996-2019

\begin{abstract}
hest inflation variation was spices, nuts, olls and fat, while the low
\end{abstract}


and milk, meat and fruits. By contrast, inflation of processed foods, beverages, cigarettes and tobacco has a slight variation and similar pattern to general inflation.

In 1998, when the economic crisis hit Indonesia from mid-1997, the percentage of the poor population increased dramatically, while in the next period, the poor population had a declining trend over time. The same percentage of poor people was reached again in 2003 as before the economic crisis. The poverty rate also increased slightly in 2006, but then consistently declined to $9.41 \%$ in 2019 . The poverty rate increase in 1998 would be closely related to the high inflation rate (Table 1). Likewise, high annual inflation in 2005 was related to the rise in the poverty rate in 2006 .

\subsection{Food expenditure share}

More than $40 \%$ of the household budget in Indonesia is spent on fulfilling food needs, although the share of food expenditure has a declining trend in recent years (Table 1). By Engel's law, this decrease indicates an increase in household welfare. The higher the income, the smaller the proportion of household expenditure allocated to food, so the share of food expenditure in urban areas is lower than in rural areas. The food expenditure share decreases with increasing income, in contrast to the increase in total food expenditure (in rupiahs), because the income elasticity of food demand is lower than those of non-food.

Changes in food expenditure share are also affected by changes in food prices. In 19981999, the food expenditure share increased dramatically because of the high foodstuffs inflation during the economic crisis. It strongly suggests the importance of maintaining affordable food prices to avoid household welfare reduction and poverty rate increase.

The highest share of food group expenditure is rice, vegetables and fish. Rice consumption is a top priority for household expenditure, with $22.03 \%$ of the household budget for food is allocated for rice purchases. Rice consumption is the highest in rural compared to urban (in line with BPS, 2021) because rural people eat more carbohydrate-rich food than urban. Rice expenditure share decreases with increasing income (see also Misdawita et al., 2019). The vegetable and fish expenditure share in rural areas is also higher than in urban areas (Table 2).

Expenditure for other foods (w14) is also quite large, mainly because of the large consumption of processed food, especially in urban and high-income groups. On the other hand, the expenditure share for each of the ten food groups is $5 \%$ or less to the total food expenditure. The consumption patterns of these food groups have not changed much in the short term (Faharuddin et al., 2019).

\subsection{Expenditure and price elasticity}

Our discussion begins with expenditure and price elasticity because the estimates of the QUAIDS model using IFGNLS on STATA software are not discussed here but presented in Table A1. Expenditure elasticity is the ratio of increased food expenditure (percent) to the total expenditure increase (percent). The price elasticity represents the change in food expenditure concerning the price change (in percent). The resulting expenditure elasticities and the price elasticities are present in Table 3.

In general, the food expenditure elasticity in urban areas is lower than in rural areas, as Devi and Purnomosidi (2019) in Java. It indicates that food consumption is still a welfare symbol of the rural residents so that the rural people will consume more food if their income increases. Most food groups have expenditure elasticity lower than 1, except for four higher prices: milk, meat, fruits and other foods. Meanwhile, rice, pulses, oils and fats, non-rice staples, beverages ingredients and vegetables are the smallest expenditure elasticities. All the expenditure elasticities are positive, which means that an increase in income would also 


\section{JABES}

\section{Table 2.}

Food group expenditure share by urban-rural and income groups

\begin{tabular}{|c|c|c|c|c|c|c|c|c|c|}
\hline \multirow[b]{2}{*}{$\begin{array}{l}\text { Variable } \\
\text { (1) }\end{array}$} & & & & \multicolumn{2}{|c|}{ Areas } & \multicolumn{3}{|c|}{ Income groups } & \multirow{2}{*}{$\begin{array}{c}\text { Overall } \\
(\%) \\
(7)\end{array}$} \\
\hline & & & & $\begin{array}{l}\text { Urban }(\%) \\
(2)\end{array}$ & $\begin{array}{c}\text { Rural }(\%) \\
(3)\end{array}$ & $\begin{array}{c}\text { Low }(\%) \\
(4)\end{array}$ & $\begin{array}{l}\text { Middle }(\%) \\
\text { (5) }\end{array}$ & $\begin{array}{l}\text { High }(\%) \\
(6)\end{array}$ & \\
\hline \multicolumn{4}{|l|}{$\mathrm{w} 1=$ rice } & 17.41 & 25.51 & 28.57 & 20.45 & 12.09 & 22.03 \\
\hline \multicolumn{4}{|c|}{ w2 $=$ non-rice staples } & 0.45 & 1.01 & 1.19 & 0.54 & 0.39 & 0.77 \\
\hline \multicolumn{4}{|c|}{$\mathrm{w} 3=$ rubers } & 0.76 & 2.70 & 2.70 & 1.48 & 0.96 & 1.86 \\
\hline \multicolumn{4}{|c|}{$\mathrm{w} 4=$ fishes } & 10.01 & 11.91 & 10.55 & 11.98 & 10.40 & 11.09 \\
\hline \multicolumn{4}{|l|}{$\mathrm{w} 5=$ meat } & 3.83 & 2.81 & 1.91 & 3.66 & 5.10 & 3.25 \\
\hline \multicolumn{4}{|l|}{$\mathrm{w} 6=$ eggs } & 2.89 & 2.58 & 2.49 & 2.97 & 2.66 & 2.71 \\
\hline \multicolumn{4}{|l|}{$\mathrm{w} 7=$ milk } & 3.55 & 1.80 & 1.38 & 2.75 & 4.51 & 2.55 \\
\hline \multicolumn{4}{|c|}{$\mathrm{w} 8=$ vegetables } & 10.24 & 12.72 & 12.97 & 11.74 & 8.85 & 11.65 \\
\hline \multicolumn{4}{|c|}{$\mathrm{w} 9=$ pulses } & 3.07 & 2.69 & 3.19 & 2.86 & 2.17 & 2.85 \\
\hline \multicolumn{4}{|c|}{$\mathrm{w} 10=$ fruits } & 5.42 & 4.83 & 3.90 & 5.30 & 7.02 & 5.08 \\
\hline \multicolumn{4}{|c|}{$\mathrm{w} 11=$ oil and grease } & 3.85 & 4.90 & 5.17 & 4.39 & 3.12 & 4.45 \\
\hline \multicolumn{4}{|c|}{$\mathrm{w} 12=$ beverage ingredients } & 4.29 & 5.86 & 5.77 & 5.24 & 3.90 & 5.18 \\
\hline \multirow{2}{*}{\multicolumn{4}{|c|}{$\mathrm{w} 13=$ spices }} & 2.24 & 2.68 & 2.72 & 2.51 & 1.97 & 2.49 \\
\hline & \multicolumn{2}{|c|}{$\mathrm{w} 14=$ processed foods and others } & & 31.99 & 18.00 & 17.49 & 24.14 & 36.84 & 24.02 \\
\hline \multicolumn{4}{|c|}{ 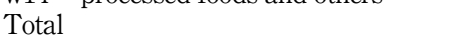 } & 100 & 100 & 100 & 100 & 100 & 100 \\
\hline \multicolumn{4}{|c|}{$\begin{array}{l}\text { Household food expenditure share to } \\
\text { total expenditure }\end{array}$} & 40.90 & 51.44 & 58.76 & 50.64 & 34.71 & 45.43 \\
\hline \multicolumn{10}{|c|}{ Source(s): Author's calculation } \\
\hline \multirow[b]{2}{*}{$\begin{array}{l}\text { Variables } \\
(1)\end{array}$} & \multicolumn{3}{|c|}{ Expenditure elasticity } & \multicolumn{3}{|c|}{$\begin{array}{l}\text { Uncompensated own-price } \\
\text { elasticity }\end{array}$} & \multicolumn{3}{|c|}{$\begin{array}{l}\text { Compensated own-price } \\
\text { elasticity }\end{array}$} \\
\hline & $\begin{array}{l}\text { Urban } \\
(2)\end{array}$ & $\begin{array}{c}\text { Rural } \\
(3)\end{array}$ & $\begin{array}{c}\text { Overall } \\
\text { (4) }\end{array}$ & $\begin{array}{l}\text { Urban } \\
(5)\end{array}$ & $\begin{array}{c}\text { Rural } \\
(6)\end{array}$ & $\begin{array}{l}\text { Overall } \\
(7)\end{array}$ & $\begin{array}{l}\text { Urban } \\
(8)\end{array}$ & $\begin{array}{c}\text { Rural } \\
(9)\end{array}$ & $\begin{array}{c}\text { Overall } \\
(10)\end{array}$ \\
\hline w1 & 0.305 & 0.462 & 0.390 & -0.420 & -0.583 & -0.508 & -0.371 & -0.479 & -0.434 \\
\hline w2 & 0.769 & 0.767 & 0.768 & -1.897 & -1.510 & -1.667 & -1.892 & -1.502 & -1.66 \\
\hline w3 & 0.728 & 0.710 & 0.718 & -1.022 & -1.015 & -1.018 & -1.016 & -1.007 & -1.01 \\
\hline w4 & 0.970 & 0.966 & 0.968 & -1.062 & -1.056 & -1.059 & -0.971 & -0.955 & -0.96 \\
\hline w5 & 1.445 & 1.564 & 1.494 & -1.180 & -1.220 & -1.197 & -1.120 & -1.166 & -1.1 \\
\hline w6 & 0.931 & 0.963 & 0.945 & -0.934 & -0.934 & -0.934 & -0.906 & -0.906 & -0.906 \\
\hline w7 & 1.650 & 1.906 & 1.740 & -0.778 & -0.656 & -0.734 & -0.710 & -0.605 & -0.675 \\
\hline w8 & 0.791 & 0.791 & 0.791 & -1.141 & -1.112 & -1.126 & -1.060 & -1.014 & -1.0 \\
\hline w9 & 0.899 & 0.913 & 0.906 & -1.376 & -1.359 & -1.368 & -1.346 & -1.327 & -1.3 \\
\hline w10 & 1.421 & 1.482 & 1.447 & -1.254 & -1.281 & -1.266 & -1.173 & -1.203 & -1.1 \\
\hline w11 & 0.720 & 0.740 & 0.730 & -1.170 & -1.136 & -1.153 & -1.143 & -1.102 & -1.12 \\
\hline w12 & 0.777 & 0.784 & 0.780 & -1.022 & -1.014 & -1.018 & -0.989 & -0.969 & -0.97 \\
\hline w13 & 0.926 & 0.925 & 0.926 & -0.879 & -0.898 & -0.889 & -0.858 & -0.873 & -0.8 \\
\hline w14 & 1.301 & 1.548 & 1.390 & -1.194 & -1.326 & -1.242 & -0.772 & -0.992 & -0.86 \\
\hline Source(s) & Author' & alculati & & & & & & & \\
\hline
\end{tabular}

increase food expenditure on all food groups. However, only four commodity groups have relatively higher differences in expenditure elasticity, namely, rice, milk, meat and other foods. Milk and meat are luxury goods, with the elasticity of milk and meat being higher than 1.5.

Regarding the own-price elasticity, all the coefficients of price elasticity are negative, consistent with demand theory, where the higher the price of food, the lower the demand for the food. Almost all commodity groups are elastic in urban and rural areas, and only four commodity groups have elasticity less than 1, namely, rice, milk, spices and eggs. However, 
only two groups show a relative difference between urban and rural areas, namely, rice and non-rice staples. Rice is price inelastic (Aftab et al., 2017), although the price elasticity of rice in rural areas is higher than in urban areas. On the contrary, the price elasticity of the non-rice staple food in rural areas is lower.

The cross-price elasticity in urban and rural areas is relatively small, less than 0.5 , and not much different between (Table A2). However, the price increase of rice and other food received the most response by household consumption. We also find that compensation can change both the absolute value of the cross-price elasticity and the sign of some of the price elasticity from negative to positive (Table A3).

\subsection{Impact of food prices increase on poverty}

The upcoming discussions will center on how rising food prices affect household welfare and poverty. First, we will explain the food price impact using $\mathrm{CV}$, and then we will move on to the poverty impact using the FGT poverty index. The rising food price's impact on household welfare varies according to the magnitude of the increase in food group prices and the expenditure share of food groups. The higher the price increase and the food group expenditure share, the higher the impact on the decline in household welfare. Thus, the highest impact on household welfare is the price increase of other foods, rice, vegetables and fish. In addition to higher food shares, these four food groups have lower income elasticities.

The increase in prices of other food groups, rice, vegetables and fish by $5 \%$ causes a decrease in welfare (in terms of CV) by $1.345,0.941,0.546$ and $0.480 \%$, respectively. The higher the price increase, the percentage of $\mathrm{CV}$ decline is also higher. At a very high price increase $(20 \%)$, the decline in household welfare is 5.025, 3.638, 2.011 and $1.777 \%$, respectively (Table 4). We also find that the impact of rising prices of rice, fish, non-rice cereals and vegetables on household welfare in rural areas is higher than in urban areas. On the other hand, the impact of rising prices for other food, meat and fruits is higher in urban household welfare.

Table 5 shows the impact of increasing food group prices on changes in poverty headcount ratio $\left(P_{0}\right)$. Similar to the above $\mathrm{CV}$ analysis, the price increases of the four food groups that have the highest poverty impact are other food groups, rice, vegetables and fish. It could be because these four food groups have the highest food expenditure share. In total,

\begin{tabular}{lcccccccccccc}
\hline & \multicolumn{1}{c}{ Urban } & \multicolumn{1}{c}{ Rural } & \multicolumn{4}{c}{ Overall } \\
Food & Sim & Sim & Sim & Sim & Sim & Sim & Sim & Sim & Sim & Sim & Sim & Sim \\
groups & 1 & 2 & 3 & 4 & 1 & 2 & 3 & 4 & 1 & 2 & 3 & 4 \\
(1) & $(2)$ & $(3)$ & $(4)$ & $(5)$ & $(6)$ & $(7)$ & $(8)$ & $(9)$ & $(10)$ & $(11)$ & $(12)$ & $(13)$ \\
\hline w1 & 0.797 & 1.578 & 2.345 & 3.097 & 1.113 & 2.199 & 3.259 & 4.291 & 0.941 & 1.860 & 2.760 & 3.638 \\
w2 & 0.030 & 0.056 & 0.080 & 0.101 & 0.052 & 0.101 & 0.145 & 0.185 & 0.040 & 0.076 & 0.109 & 0.139 \\
w3 & 0.042 & 0.081 & 0.118 & 0.154 & 0.058 & 0.113 & 0.166 & 0.215 & 0.049 & 0.096 & 0.140 & 0.181 \\
w4 & 0.458 & 0.893 & 1.306 & 1.695 & 0.506 & 0.987 & 1.443 & 1.874 & 0.480 & 0.936 & 1.368 & 1.777 \\
w5 & 0.203 & 0.395 & 0.574 & 0.742 & 0.168 & 0.325 & 0.472 & 0.610 & 0.187 & 0.363 & 0.528 & 0.682 \\
w6 & 0.146 & 0.285 & 0.418 & 0.543 & 0.144 & 0.282 & 0.413 & 0.538 & 0.145 & 0.284 & 0.416 & 0.541 \\
w7 & 0.200 & 0.392 & 0.578 & 0.756 & 0.131 & 0.258 & 0.381 & 0.501 & 0.169 & 0.331 & 0.488 & 0.640 \\
w8 & 0.495 & 0.964 & 1.405 & 1.820 & 0.608 & 1.184 & 1.728 & 2.241 & 0.546 & 1.064 & 1.552 & 2.011 \\
w9 & 0.157 & 0.303 & 0.438 & 0.562 & 0.166 & 0.320 & 0.464 & 0.595 & 0.161 & 0.311 & 0.449 & 0.577 \\
w10 & 0.277 & 0.537 & 0.781 & 1.008 & 0.254 & 0.492 & 0.715 & 0.922 & 0.267 & 0.517 & 0.751 & 0.969 \\
w11 & 0.181 & 0.351 & 0.511 & 0.659 & 0.225 & 0.437 & 0.636 & 0.822 & 0.201 & 0.390 & 0.567 & 0.733 \\
w12 & 0.209 & 0.407 & 0.594 & 0.771 & 0.280 & 0.546 & 0.799 & 1.037 & 0.241 & 0.470 & 0.687 & 0.892 \\
w13 & 0.111 & 0.216 & 0.317 & 0.413 & 0.131 & 0.256 & 0.376 & 0.489 & 0.120 & 0.234 & 0.344 & 0.448 \\
w14 & 1.590 & 3.117 & 4.582 & 5.984 & 1.052 & 2.051 & 2.996 & 3.887 & 1.345 & 2.631 & 3.857 & 5.025
\end{tabular}

Source(s): Author's calculation

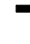




\begin{tabular}{lcccccccccccc}
\hline \multicolumn{1}{c}{ Urban } & \multicolumn{1}{c}{ Rural } & \multicolumn{4}{c}{ Overall } \\
Food & Sim & Sim & Sim & Sim & Sim & Sim & Sim & Sim & Sim & Sim & Sim & Sim \\
groups & 1 & 2 & 3 & 4 & 1 & 2 & 3 & 4 & 1 & 2 & 3 & 4 \\
$(1)$ & $(2)$ & $(3)$ & $(4)$ & $(5)$ & $(6)$ & $(7)$ & $(8)$ & $(9)$ & $(10)$ & $(11)$ & $(12)$ & $(13)$ \\
\hline
\end{tabular}

Impact on poverty headcount ratio $\left(P_{0}\right)$

$\begin{array}{lllllllllllll}\text { w1 } & 0.241 & 0.414 & 0.591 & 0.812 & 0.429 & 0.927 & 1.349 & 1.774 & 0.348 & 0.706 & 1.023 & 1.360 \\ \text { w2 } & 0.014 & 0.017 & 0.025 & 0.036 & 0.025 & 0.044 & 0.065 & 0.088 & 0.020 & 0.032 & 0.048 & 0.066 \\ \text { w3 } & 0.014 & 0.025 & 0.038 & 0.056 & 0.030 & 0.047 & 0.072 & 0.093 & 0.023 & 0.038 & 0.058 & 0.077 \\ \text { w4 } & 0.180 & 0.275 & 0.369 & 0.437 & 0.185 & 0.372 & 0.567 & 0.787 & 0.183 & 0.330 & 0.482 & 0.636 \\ \text { w5 } & 0.075 & 0.166 & 0.201 & 0.166 & 0.075 & 0.121 & 0.171 & 0.121 & 0.075 & 0.140 & 0.184 & 0.140 \\ \text { w6 } & 0.009 & 0.014 & 0.014 & 0.017 & 0.004 & 0.014 & 0.022 & 0.025 & 0.007 & 0.014 & 0.019 & 0.022 \\ \text { w7 } & 0.075 & 0.157 & 0.201 & 0.224 & 0.056 & 0.099 & 0.140 & 0.185 & 0.065 & 0.124 & 0.166 & 0.201 \\ \text { w8 } & 0.194 & 0.290 & 0.389 & 0.465 & 0.213 & 0.451 & 0.718 & 0.944 & 0.205 & 0.382 & 0.576 & 0.737 \\ \text { w9 } & 0.056 & 0.139 & 0.175 & 0.197 & 0.072 & 0.121 & 0.171 & 0.209 & 0.065 & 0.128 & 0.173 & 0.204 \\ \text { w10 } & 0.121 & 0.194 & 0.236 & 0.304 & 0.099 & 0.181 & 0.249 & 0.356 & 0.108 & 0.186 & 0.243 & 0.334 \\ \text { w11 } & 0.063 & 0.148 & 0.194 & 0.208 & 0.095 & 0.162 & 0.228 & 0.317 & 0.081 & 0.156 & 0.213 & 0.270 \\ \text { w12 } & 0.075 & 0.166 & 0.201 & 0.236 & 0.101 & 0.194 & 0.295 & 0.401 & 0.090 & 0.182 & 0.255 & 0.330 \\ \text { w13 } & 0.036 & 0.081 & 0.139 & 0.169 & 0.056 & 0.099 & 0.138 & 0.179 & 0.047 & 0.091 & 0.138 & 0.174 \\ \text { w14 } & 0.417 & 0.814 & 1.194 & 1.569 & 0.417 & 0.860 & 1.224 & 1.607 & 0.417 & 0.840 & 1.211 & 1.591\end{array}$

Impact on poverty gap index $\left(P_{1}\right)$

\begin{tabular}{|c|c|c|c|c|c|c|c|c|c|c|c|c|}
\hline w1 & 0.078 & 0.156 & 0.234 & 0.313 & 0.039 & 0.078 & 0.118 & 0.157 & 0.107 & 0.214 & 0.323 & 0.432 \\
\hline w2 & 0.003 & 0.007 & 0.009 & 0.012 & 0.001 & 0.003 & 0.004 & 0.005 & 0.005 & 0.010 & 0.014 & 0.018 \\
\hline w3 & 0.004 & 0.008 & 0.011 & 0.015 & 0.002 & 0.004 & 0.006 & 0.007 & 0.005 & 0.011 & 0.016 & 0.020 \\
\hline w4 & 0.037 & 0.073 & 0.107 & 0.140 & 0.022 & 0.044 & 0.065 & 0.084 & 0.048 & 0.094 & 0.139 & 0.182 \\
\hline w5 & 0.013 & 0.026 & 0.038 & 0.049 & 0.010 & 0.019 & 0.028 & 0.036 & 0.016 & 0.031 & 0.045 & 0.058 \\
\hline w6 & 0.001 & 0.002 & 0.003 & 0.004 & 0.001 & 0.001 & 0.002 & 0.003 & 0.001 & 0.003 & 0.004 & 0.005 \\
\hline w7 & 0.011 & 0.022 & 0.033 & 0.043 & 0.010 & 0.019 & 0.028 & 0.037 & 0.012 & 0.024 & 0.036 & 0.048 \\
\hline w8 & 0.043 & 0.085 & 0.125 & 0.163 & 0.024 & 0.047 & 0.070 & 0.091 & 0.058 & 0.114 & 0.167 & 0.219 \\
\hline w9 & 0.012 & 0.024 & 0.034 & 0.044 & 0.008 & 0.015 & 0.021 & 0.027 & 0.016 & 0.030 & 0.044 & 0.057 \\
\hline 10 & 0.019 & 0.038 & 0.055 & 0.072 & 0.013 & 0.026 & 0.038 & 0.050 & 0.024 & 0.047 & 0.068 & 0.088 \\
\hline 11 & 0.016 & 0.031 & 0.045 & 0.059 & 0.009 & 0.017 & 0.025 & 0.032 & 0.021 & 0.042 & 0.061 & 0.078 \\
\hline 12 & 0.019 & 0.038 & 0.056 & 0.073 & 0.010 & 0.020 & 0.029 & 0.038 & 0.027 & 0.052 & 0.076 & 0.099 \\
\hline 13 & 0.009 & 0.018 & 0.027 & 0.035 & 0.005 & 0.010 & 0.015 & 0.020 & 0.012 & 0.024 & 0.036 & 0.046 \\
\hline 14 & 0.091 & 0.182 & 0.271 & 0.358 & 0.079 & 0.158 & 0.238 & 0.317 & 0.101 & 0.200 & 0.296 & 0.389 \\
\hline \multicolumn{13}{|c|}{ Impact on poverty severity index $\left(P_{2}\right)$} \\
\hline w1 & 0.024 & 0.048 & 0.073 & 0.098 & 0.012 & 0.023 & 0.035 & 0.047 & 0.033 & 0.067 & 0.102 & 0.137 \\
\hline w2 & 0.001 & 0.002 & 0.003 & 0.004 & 0.000 & 0.001 & 0.001 & 0.001 & 0.002 & 0.003 & 0.004 & 0.005 \\
\hline D & 0.001 & 0.002 & 0.004 & 0.005 & 0.001 & 0.001 & 0.002 & 0.002 & 0.002 & 0.003 & 0.005 & 0.006 \\
\hline W4 & 0.011 & 0.022 & 0.033 & 0.043 & 0.007 & 0.013 & 0.019 & 0.025 & 0.015 & 0.029 & 0.043 & 0.057 \\
\hline w5 & 0.004 & 0.008 & 0.012 & 0.015 & 0.003 & 0.006 & 0.008 & 0.011 & 0.005 & 0.010 & 0.014 & 0.018 \\
\hline w6 & 0.000 & 0.001 & 0.001 & 0.001 & 0.000 & 0.000 & 0.001 & 0.001 & 0.000 & 0.001 & 0.001 & 0.002 \\
\hline w7 & 0.003 & 0.007 & 0.010 & 0.013 & 0.003 & 0.006 & 0.008 & 0.011 & 0.004 & 0.008 & 0.011 & 0.015 \\
\hline w8 & 0.013 & 0.026 & 0.039 & 0.051 & 0.007 & 0.014 & 0.021 & 0.027 & 0.018 & 0.036 & 0.052 & 0.069 \\
\hline 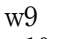 & 0.004 & 0.007 & 0.011 & 0.014 & 0.002 & 0.004 & 0.006 & 0.008 & 0.005 & 0.009 & 0.014 & 0.018 \\
\hline 10 & 0.006 & 0.012 & 0.017 & 0.022 & 0.004 & 0.008 & 0.011 & 0.015 & 0.007 & 0.015 & 0.021 & 0.028 \\
\hline 11 & 0.005 & 0.010 & 0.014 & 0.018 & 0.003 & 0.005 & 0.007 & 0.010 & 0.007 & 0.013 & 0.019 & 0.024 \\
\hline 12 & 0.006 & 0.012 & 0.017 & 0.022 & 0.003 & 0.006 & 0.009 & 0.011 & 0.008 & 0.016 & 0.024 & 0.031 \\
\hline & 0.003 & 0.006 & 0.008 & 0.011 & 0.002 & 0.003 & 0.005 & 0.006 & 0.004 & 0.008 & 0.011 & 0.014 \\
\hline & 0.028 & 0.056 & 0.084 & 0.111 & 0.023 & 0.047 & 0.071 & 0.096 & 0.031 & 0.063 & 0.093 & 0.123 \\
\hline
\end{tabular}

Table 5 .
Impact of food price increase on poverty rate by rural-urban

Source(s): Author's calculation

$5 \%$ of the price increase of other foods, rice, vegetables and fish causes an increase in the percentage of poor people respectively by $0.417,0.348,0.205$ and 0.183 points. The higher the price increases, the higher the impact on poverty, even though not linear. The $20 \%$ increase in 
the price of each food group causes an increase in poverty headcount ratio 1.591 points (other food), 1.360 points (rice), 0.737 points (vegetables) and 0.636 points (fish).

Using a poverty line of US $\$ 1.25$ per capita per day, Ivanic et al. (2012) found that a $20 \%$ increase in world rice prices caused an increase in the poverty headcount ratio in Indonesia by 0.57 points from the original $7.5 \%$ in 2010 . This finding is higher than Ivanic et al. (2012) and Warr and Yusuf (2013). The difference could be because of domestic food prices used here, and we do not consider the positive impact of rising food prices on food-producing households. The increase in food prices in rural areas reduces the negative impact on rural poverty because the income of food-producing households is rising (Friedman and Levinsohn, 2002). However, the effect is relatively small (Warr and Yusuf, 2013).

The effect of rising food prices on poverty in rural areas is higher than in urban areas, in line with Warr and Yusuf (2013) and Misdawita et al. (2019), especially for the four food groups. An increase of $20 \%$ in the price of these food groups increases the percentage of poor people by 1.774 points in rural areas and 0.812 points in urban areas (rice); 1.607 points in rural areas and 1.569 points in urban areas (other foods); 0.944 points in rural areas and 0.465 points in urban areas (vegetables); 0.787 points in rural areas and 0.437 points in urban areas (fish). Even though farmers mostly live in rural, Warr and Yusuf (2013) argue that the beneficiaries of rising food prices in rural areas are not rural poor people but landowners, many of whom live in urban areas.

This study reveals that price increases in foods that are frequently monitored by the government (other than rice), such as meat, granulated sugar (beverage ingredients), chilies (spices) and onions (spices), have a relatively lower impact on poverty. It is due to these food groups having a relatively small share of expenditure (Table 2). A $20 \%$ of price increase caused an increase in the poverty rate by 0.140 points (meat), 0.330 points (beverage ingredients) and 0.174 points (spices). However, the rise of these foods prices usually politically draws public attention because some are imported foodstuffs. However, the government needs to be aware of the high increases in food commodity prices simultaneously. If the prices of all food groups increase simultaneously by $20 \%$, the percentage of the poor will increase by 6.142 points. For example, if all food prices increased by $20 \%$ in 2020 , the poverty headcount ratio would be increased from $9.41 \%$ in 2019 to $15.55 \%$ in 2020 . This increase in food prices for all food commodities by $20 \%$ also impacts rural poverty more than urban areas (7.086 points increase in rural poverty headcount ratio and 4.896 points increase in urban poverty).

The effect of rising food prices on other poverty indicators, namely, the poverty gap index and poverty severity index, has a similar pattern to the impact of food prices on the headcount ratio as described above. The higher effect also comes from the four food groups, namely, other foods, rice, vegetables and fish (Table 4).

\section{Conclusion and policy implications}

Using household survey data, we use demand analysis to calculate the impact of rising food group prices on household welfare and poverty in Indonesia. The welfare measure used is CV to calculate the impact of price increases on changes in household consumption. The 2013 national poverty line then applied to obtain the magnitude of rising prices' impact on increasing poverty. Although we did not take into account the relatively minor positive impact of rising food prices on the increasing income of food-producing households, the findings of this study will be extremely useful for government policies aimed at controlling food prices and combating poverty. The findings of this study support previous studies regarding the negative impact of rising food prices on reducing household welfare and increasing poverty. This negative impact is higher in rural households than in urban areas. The highest impact comes from the price increase of the highest expenditure share food 
groups; rice, vegetables and fish. A very high price increase $(20 \%)$ causes an increase in poverty incidence 1.591 points (other food), 1.360 points (rice), 0.737 points (vegetables) and 0.360 points (fish). Conversely, the increase in prices of other foodstuffs, meat, sugar (beverage ingredients), chilies (spices) and onions (spices) have a relatively small impact.

Our findings suggest some policies recommendation to reduce the negative impacts of this high food price increase. To begin with, people need appropriate food price policies to avoid uncontrolled price increases in the short run. However, as mentioned above, high food prices are harmful to consumers, even though some food producers benefit from increased income. The pricing policy should be predominantly for food commodities with a large share of expenditure and higher poverty impact. If price stability sustains during the current COVID-19 pandemic, a dramatic increase in poverty incidence in Indonesia might not occur.

In addition, the price policies must execute in conjunction with other consumer protection policies such as food aid or cash transfer for the lowest income population. Based on the findings above, this policy will reduce the expenditure burden of vulnerable groups due to rising food prices. The protection policies for the poor were an effective anti-poverty program during the crisis in 1997-1999 (Dhanani and Islam, 2002).

Finally, this study also recommends rural development policies and promotes agricultural growth. In addition to the higher poverty impact on the rural population, the rural areas are generally identical with agriculture as food producers. In the long term, investment in agriculture, especially food crops, will increase food security through domestic food sufficiency. Agricultural economic growth is also crucial in poverty alleviation in Indonesia (Suryahadi et al., 2009). Increasing domestic food production will protect the country against international food price increases (Headey, 2018).

This paper does not consider the positive impact of rising food prices on food-producing households. Although the effect is relatively small, we recommend that further research should take this into account. The calculations will be more sophisticated, but the model will be more exhaustive. It is also necessary to conduct research using different methods and up-to-date data to enrich the analysis of the impact of rising food prices in Indonesia.

\section{References}

Adekunle, C.P., Akinbode, S.O., Shittu, A.M. and Momoh, S. (2020), "Food price changes and farm households' welfare in Nigeria: direct and indirect approach", Journal of Applied Economics, Vol. 23 No. 1, pp. 409-425.

Aftab, S., Yaseen, M.R. and Anwar, S. (2017), "Impact of rising food prices on consumer welfare in the most populous countries of South Asia", International Journal of Social Economics, Vol. 44 No. 8, pp. 1062-1077.

Allo, A.G., Satriawan, E. and Arsyad, L. (2018), "The impact of rising food prices on farmers' welfare in Indonesia”, Journal of Indonesian Economy and Business, Vol. 33 No. 3, pp. 193-215.

Attanasio, O.V., Di Maro, V., Lechene, V. and Philips, D. (2013), "Welfare consequences of food prices increases: evidence from rural Mexico", Journal of Development Economics, Vol. 104, pp. 136-151.

Banks, J., Blundell, R. and Lewbel, A. (1997), "Quadratic Engel curves and consumer demand”, The Review of Economics and Statistics, Vol. 79 No. 4, pp. 527-539.

BPS (2010), Analisis dan Penghitungan Tingkat Kemiskinan 2010 (The Analysis and Measurement of Poverty 2010), Badan Pusat Statistik, Jakarta.

BPS (2019), Penghitungan dan Analisis Kemiskinan Makro di Indonesia Tahun 2019 (The Measurement and Analysis of Poverty in Indonesia, 2019), Badan Pusat Statistik, Jakarta. 
BPS (2021), Pengeluaran untuk Konsumsi Penduduk Indonesia 2021: Berdasarkan Susenas Maret 2019 (Expenditure for Consumption of Population of Indonesia 2021, Based on The 2021 March Susenas), Badan Pusat Statistik, Jakarta.

Caracciolo, F., Depalo, D. and Macias, J.B. (2013), "Food price changes and poverty in Zambia: an empirical assessment using household microdata”, Journal of International Development, Vol. 26 No. 4, pp. 492-507.

De Hoyos, R.E. and Medvedev, D. (2011), "Poverty effects of higher food prices: a global perspective", Review of Development Economics, Vol. 15 No. 3, pp. 387-402.

Deaton, A. (1987), "Estimation of own- and cross-price elasticities from household survey data", Journal of Econometrics, Vol. 36 Nos 1-2, pp. 7-30.

Devi, L. and Purnomosidi, R. (2019), "Estimation of demand elasticity for food commodities in Java Island", JEJAK: Jurnal Ekonomi dan Kebijakan, Vol. 12 No. 1, pp. 54-67.

Dhanani, S. and Islam, I. (2002), "Poverty, vulnerability and social protection in a period of crisis: the case of Indonesia", World Development, Vol. 30 No. 1, pp. 1211-1233.

Faharuddin, F., Mulyana, A., Yamin, M. and Yunita, Y. (2017), "Nutrient elasticities of food consumption: the case of Indonesia", Journal of Agribusiness in Developing and Emerging Economies, Vol. 7 No. 3, pp. 198-217.

Faharuddin, F., Yunita, Y., Mulyana, A. and Yamin, M. (2019), “Agricultural households' food demand: evidence from Indonesia”, Asian Journal of Agriculture and Development, Vol. 16 No. 2, pp. 45-58.

Ferreira, F.H.G., Fruttero, A., Leite, P.G. and Lucchetti, L.R. (2013), "Rising food prices and household welfare: evidence from Brazil in 2008”, Agricultural Economics, Vol. 64 No. 1, pp. 151-176.

Foster, J., Greer, J. and Thorbecke, E. (1984), “A class of decomposable poverty measures", Econometrica, Vol. 52 No. 3, pp. 761-766.

Friedman, J. and Levinshon, J. (2002), "The distributional impacts of Indonesia's financial crisis on household welfare: a 'rapid response' methodology", The World Bank Economic Review, Vol. 16 No. 3, pp. 397-423.

Fujii, T. (2013), "Impact of food inflation on poverty in the Philippines", Food Policy, Vol. 39, pp. 13-27.

Haughton, J. and Khandker, S.R. (2009), Handbook on Poverty and Inequality, The World Bank, Washington, District of Columbia.

Headey, D.D. (2018), "Food prices and poverty", The World Bank Economic Review, Vol. 32 No. 3, pp. 676-691.

Hoang, L.V. (2009), "Estimation of food demand from household survey data in Vietnam", Depocen Working Paper Series No. 2009/12.

Hovhannisyan, V. and Shanoyan, A. (2020), "An empirical analysis of the welfare consequences of rising food prices in urban China: the Easi approach", Applied Economic Perspectives and Policy, Vol. 42 No. 4, pp. 796-814.

Ivanic, M. and Martin, W. (2008), "Implication of higher global food prices for poverty in low-income countries", Agricultural Economics, Vol. 39 No. Supplement, pp. 405-416.

Ivanic, M. and Martin, W. (2014), "Short- and long-run impacts of food price changes on poverty", Policy Research Working Paper No. 7011, Development Research Group, Agriculture and Rural Development Team.

Ivanic, M., Martin, W. and Zaman, H. (2012), "Estimating the short-run poverty impacts of the 2010-11 surge in food prices", World Development, Vol. 40 No. 11, pp. 2302-2317.

Khoiriyah, N., Anindita, R., Hanani, N. and Muhaimin, A.W. (2020), "Animal food demand in Indonesia: a quadratic almost ideal demand system approach", AGRIS on-Line Papers in Economics and Informatics, Vol. 12 No. 2, pp. 85-97.

McCulloch, N. (2008), "Rice prices and poverty in Indonesia", Bulletin of Indonesian Economic Studies, Vol. 44 No. 1, pp. $45-64$. 
Misdawita, M., Hartono, J. and Nugroho, A. (2019), "Impacts of food prices on the economy: social accounting matrix and microsimulation approach in Indonesia", Review of Urban and Regional Development Studies, Vol. 31 Nos 1-2, pp. 137-154.

Pangaribowo, E.H. and Tsegai, D. (2011), "Food demand analysis of Indonesian households with particular attention to the poorest", ZEF-Discussion Papers on Development Policy No. 151.

Poi, B.P. (2012), "Easy demand-system estimation with quaids", Stata Journals, Vol. 12 No. 3, pp. 433-446.

Ravallion, M. (2012), "Poverty lines across the world", in Jefferson, P.N. (Ed.), Oxford Handbook of the Economics of Poverty, Oxford University Press.

Robles, M. and Torero, M. (2010), "Understanding the impact of high food prices in Latin America", Economia, Vol. 10 No. 2, pp. 117-159.

Suryahadi, A. and Sumarto, S. (2003), "Poverty and vulnerability in Indonesia before and after the economic crisis", Asian Economic Journal, Vol. 17 No. 1, pp. 45-64.

Suryahadi, A., Suryadarma, D. and Sumarto, S. (2009), "The effects of location and sectoral components of economic growth on poverty: evidence from Indonesia", Journal Development Economics, Vol. 89 No. 1, pp. 109-117.

Valero-Gill, J.N. and Valero, M. (2008), "The effects of rising food prices on poverty in Mexico", Agricultural Economics, Vol. 39 No. Supplement, pp. 485-496.

Vu, L. and Glewwe, P. (2011), "Impacts of rising food prices on poverty and welfare in Vietnam", Journal of Agricultural and Resource Economics, Vol. 36 No. 1, pp. 14-27.

Warr, P. and Yusuf, A.A. (2013), "World food prices and poverty in Indonesia", The Australian Journal of Agricultural and Resource Economics, Vol. 58 No. 1, pp. 1-21.

Widarjono, A. (2012), "Food and nutrient demand in Indonesia”, Unpublished dissertation, Oklahoma State University.

World Bank (2020), Poverty and Shared Prosperity 2020: Reversals of Fortune, World Bank, Washington, District of Columbia.

Yu, X. (2014), "Raising food prices and welfare change: a simple calibration", Applied Economics Letters, Vol. 21 No. 9, pp. 643-645.

\section{Corresponding author}

Faharuddin Faharuddin can be contacted at: fahar26@gmail.com 


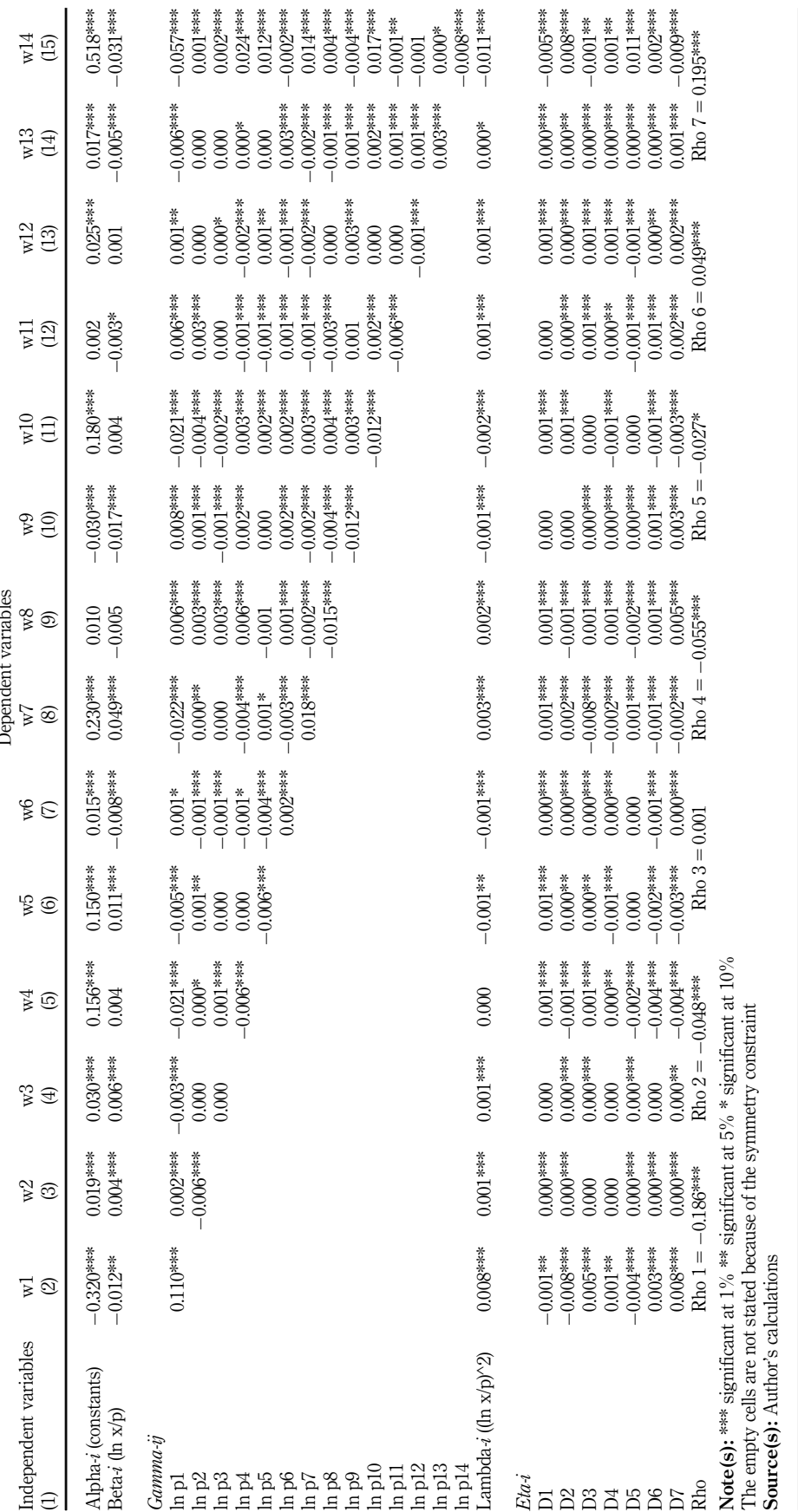

Table A1. 
JABES

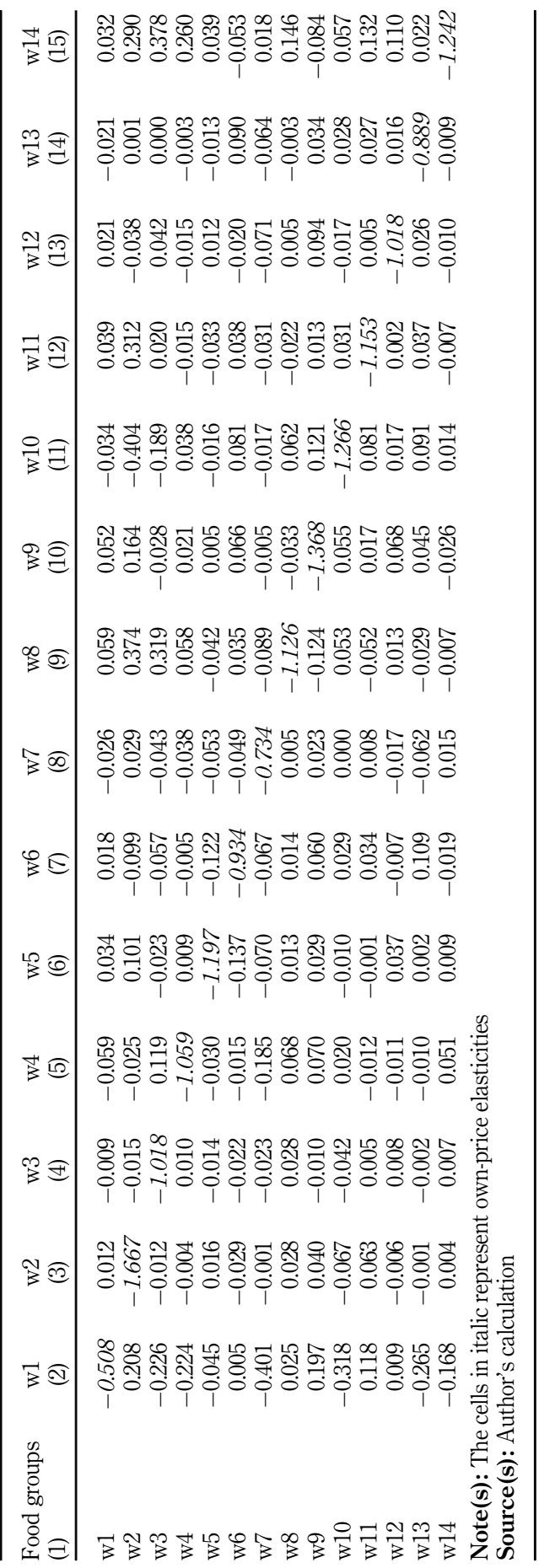

Table A2.

Uncompensated crossprice elasticities (Marshallian) 
